\title{
EFEKTIFITAS ABU SEKAM PADI DAN POLY ALUMINIUM CHLORIDE DALAM MENURUNKAN ZAT WARNA LIMBAH CAIR INDUSTRI SASIRANGAN
}

\author{
Luqman Nur Hakim, Syarifudin A, Sulaiman Hamzani \\ Poltekkes Kemenkes Banjarmasin Jurusan Kesehatan Lingkungan \\ Jl.H.M.Cokrokusumo No.1A Kota Banjarbaru \\ Email : luqman.nurhakim08@gmail.com
}

\begin{abstract}
Effectiveness Of Rice Husk Ash And Poly Aluminum Chloride In Reducing Exposure Colour Liquid Waste Industry Sasirangan. Sasirangan fabric industry is the textile of industry in Kalimantan Selatan produce wastewater of dyeing cloth sasirangan process that uses water as a primary adjuvant in stage process.The study aims to determine the effectiveness of rice husk ash and Poly Aluminium Chloridereduce levels of dyes in wastewater sasirangan "Oriens Handycraft". This study tested a laboratory scale with dose variation of rice husk ash and Poly Aluminium Chloride for reduced levels of dyes in wastewater sasirangan. The study design is a randomized pretest - posttest control group design. The population of the waste liquid fabric manufacturesasirangan results and samples are the waste from the manufacture of cloth sasirangan which represents the population. This study conduct statistical tests usingKruskal Wallis and Mann-Whitney Test.Theresultsofthestudyof color levels priorto treatment equal to 2,712 PtCo and after treatment ranges from 676.3 to $978.7 \mathrm{PtCo}$ at a dose of 58 grams of rice husk ash; $59 \mathrm{~g} ; 60 \mathrm{~g}$; $61 \mathrm{~g} ; 62 \mathrm{gr}$ and Poly Aluminium Chloride $0.5 \mathrm{gr}$. For a dose of 58 grams of rice husk ash; 59 g; 60 g; 61 g; 62 gr and Poly Aluminium Chloride $1 \mathrm{~g}$ of color levels before treatment and after PtCo 1775 amounted to 227.7 PtCo ranges up to 240 PtCo. Rice husk ash and Poly Aluminium Chloride effective at pH 6.5 - 7. Results of normality test showed abnormal data. Kruskal Wallis test probability value $0.002<0.05$, there is a difference between the average dosing in the control group and the treatment group and the Mann-Whitney Test probability value of $0.009(0.018<0.05)$, the rice husk ash dosing and Poly Aluminium Chloride $1 \mathrm{~g}$ more effective than rice husk ash dosing and Poly Aluminium Chloride 0.5 g.Efforts government can do is provide the appropriate policy on effluent quality standards and attention to industrial waste disposal sasirangan. For the industry can manage its waste before waste into the environment.
\end{abstract}

Keywords : :SasiranganWaste,Materials coagulant,pH,Dyes

\begin{abstract}
Abstrak : Efektifitas Abu Sekam Padi Dan Poly Aluminium Chloride Dalam Menurunkan Zat Warna Limbah Cair Industri Sasirangan. Industri kain sasirangan merupakan industri tekstil di Kalimantan Selatan menghasilkan limbah cair dari proses pewarnaan kain sasirangan yang menggunakan air sebagai bahan pembantu utama dalam tahapan prosesnya. Tujuan mengetahui efektifitas abu sekam padi dan Poly Aluminium Chloride menurunkan kadar zat warna limbah cair industri sasirangan "Oriens Handycraft". Penelitian ini melakukan uji coba skala laboratorium dengan variasi dosis Abu sekam padi dan Poly Aluminium Chloride untuk penurunan kadar zat warna pada limbah cair sasirangan. Rancangan penelitian adalah The Randomized Pretest - Posttest Control Group Design. Populasinya seluruh limbah cair hasil pembuatan kain sasirangan dan Sampelnya limbah dari hasil pembuatan kain sasirangan yang mewakili populasi. Uji statistik penelitian ini dengan menggunakan Uji Kruskal Wallis dan Mann-Whitney Test._Hasil penelitian kadar warna sebelum perlakuan sebesar 2.712 PtCo dan sesudah perlakuan berkisar 676,3 PtCo hingga 978,7 PtCo pada dosis abu sekam padi 58 gr; 59 gr; 60 gr; 61 gr; 62 gr dan Poly Aluminium Chloride 0,5 gr. Untuk dosis abu sekam padi 58 gr; 59 gr; 60 gr; 61 gr; 62 gr dan Poly Aluminium Chloride 1 gr kadar warna sebelum perlakuan sebesar 1.775 PtCo dan sesudah berkisar 227,7 PtCo hingga 240 PtCo. Abu sekam padi dan Poly Aluminium Chloride efektif pada pH 6,5 - 7. Hasil uji normalitas menunjukkan data tidak normal. Uji Kruskal Wallis nilai probabilitasnya $0,002<0,05$, maka ada perbedaan antara rata-rata pemberian
\end{abstract}


dosis pada kelompok kontrol dan kelompok perlakuan dan Uji Mann-Whitney Test nilai probabilitasnya 0,009 $(0,018<0,05)$ maka pemberian dosis Abu sekam padi dan Poly Aluminium Chloride 1 gr lebih efektif daripada pemberian dosis Abu sekam padi dan Poly Aluminium Chloride 0,5 gr. Upaya yang dapat dilakukan pemerintah adalah memberi kebijakan yang sesuai tentang baku mutu limbah cair dan memperhatikan pembuangan limbah industri sasirangan. Bagi industri dapat mengelola limbahnya sebelum di buang ke lingkungan.

\section{Kata Kunci : Limbah Sasirangan, Bahan Koagulan, pH, Zat Warna}

\section{PENDAHULUAN}

Limbah industri menjadi semakin bertambah seiring dengan pesatnya perkembangan industri, baik volume dan jenis limbah. Limbah industri khususnya industri tekstil merupakan salah satu penyebab masalah dari buangan limbah tersebut dapat mencemari lingkungan. Salah satu masalah yang paling mengganggu dari limbah industri tersebut adalah kandungan zat warna (1).

Industri kain sasirangan yang termasuk dalam salah satu dari industri tekstil yang ada di Kalimantan Selatan dalam proses produksinya menghasilkan limbah cair hal ini disebabkan dari proses penyempurnaan tekstil yang selalu menggunakan air sebagai bahan pembantu utama dalam setiap tahapan prosesnya. Pencemaran air dari industri kain sasirangan berasal dari buangan air proses produksi, buangan bahan-bahan kimia sisa proses produksi, sampah potongan kain dan lainnya. Pencemaran itu mengganggu keseimbangan ekosistem sungai, merubah warna air, bau bahkan mengakibatkan matinya makhluk hidup di air yang sangat penting bagi kehidupan manusia. Pada pewarnaan kain sasirangan, zat warna yang sering digunakan adalah zat warna naphtol dan indanthrene dengan garam sebagai bahan pembantunya yaitu soda api $(\mathrm{NaOH})$, TRO/Sepritus, hydro dan air panas (2).

Limbah sekam padi merupakan hasil samping dari proses penggilingan padi. Bila kondisi ini berjalan sesuai dengan kapasitasnya, akan menghasilkan limbah sekam padi sebesar 8 juta ton. Pemanfaatan limbah sekam padi sangat penting untuk menjaga lingkungan (3).Abu sekam padi lebih sering digunakan untuk keperluan seperti abu gosok dan media tanaman, bahkan dibuang begitu saja. Abu sekam padi banyak mengandung silika $\left(\mathrm{SiO}_{2}\right)$ sebesar $94 \%$ - 96\% dan apabila nilainya di bawah $90 \%$ maka sekam padi telah terkontaminasi oleh zat lain (4). Penelitian Cahyonugroho, 2007 menjelaskan bahwa silika merupakan senyawa yang dapat dipakai sebagai adsorben. Laju adsorpsi yang ditunjukkan oleh volume reagen yang ditambahkan, semakin besar volume reagen semakin besar adsorpsinya. Adsorpsi merupakan serangkaian proses penyerapan permukaan zat padat (adsorben) seperti silika dari kandungan Abu Sekam Padi dengan zat pencemar warna dari limbah tekstil yang diserap disebut juga sebagai adsorbat (6).

Berdasarkan beberapa penelitian diatas maka Peneliti menggunakan abu sekam padi sebagai karbon aktif yang mengandung silika $\left(\mathrm{SiO}_{2}\right)$ untuk menyerap atau menangkap zat pencemar warna yang terkandung pada limbah cair sasirangan dengan penambahan Poly Aluminium Chloride atau $\mathrm{Al}_{n}(\mathrm{OH})_{\mathrm{m}} \mathrm{Cl}_{3 \mathrm{n}-\mathrm{m}}$ akan mempercepat proses adsorpsi tersebut.Berdasarkan data dari Dinas Perindustrian Perdagangan Pertambangan dan Energi tahun 2015 di banjarbaru, landasan ulin dan cempaka memiliki 15 buah industri kain sasirangan dan dari survey ke 15 industri tersebut kebanyakan membuang air limbah hasil olahan kain sasirangan ke tanah dan saluran air. Dari hal tersebut peneliti hanya mengambil satu tempat industri sasirangan yaitu pada tanggal 27 - 28 Januari 2016 melakukan observasi ke Home industri kain sasirangan "Oriens Handycraft" dilandasan ulin kota banjarbaru. Produksi kain sasirangan memerlukan kain sebanyak $10-100$ lembar kain dalam sekali produksi dengan kebutuhan air 30 liter/100 lembar kain 
sasirangan. Pada Home industri kain sasirangan "Oriens Handycraft", tidak terdapat tempat pengolahan limbah cair kain sasirangan, limbah hasil pewarnaan langsung di buang ke tanah tanpa adanya upaya pengolahan terlebih dahulu.

Dari hasil uji coba pendahuluan di laboratorium kimia jurusan kesehatan lingkungan sampel limbah cair sasirangan sebelum perlakuan didapatkan konsentrasi zat warna sebesar 280 PtCo dengan membandingkan angka baku mutu limbah cari industri batik menurut Peraturan Gubernur Daerah Istimewa Yogyakarta Nomor 7 Tahun 2010 yaitu 50 PtCo maka konsentrasi zat warna pada sampel limbah cair sasirangan masih tinggi.

Secara umum tujuan penelitian ini mengetahui efektifitas abu sekam padi dan Poly Aluminium Chloridedalam menurunkan kadar zat warna pada limbah cair industri sasirangan "oriens handycraft", dengan mengetahuinya kadar warna pada limbah cair sasirangan sebelum dan sesudah pengolahan, dosis optimum abu sekam padi dan bahan aktif Poly Aluminium Chloride dalam menurunkan kadar warna pada limbah cair sasirangan dan hasil uji statistik perbedaan kadar warna limbah cair sasirangan.

\section{BAHAN DAN CARA PENELITIAN}

Desain penelitian ini adalah The Randomized Pretest - Posttest Control Group Design yaitu rancangan penelitian yang mengelompokkan anggota-anggota kelompok kontrol dan kelompok eksperimen yang dilakukan secara acak atau random. Kemudian dilakukan pretest (01) pada kedua kelompok tersebut, dan diikuti intervensi (X) pada kelompok eksperimen. Setelah beberapa waktu dilakukan postest (02) pada kedua kelompok tersebut. Dengan randomisasi (R), maka kedua kelompok mempunyai sifat yang sama sebelum dilakukan intervensi (perlakuan). Karena kedua kelompok sama pada awalnya, maka perbedaan hasil postest (02) pada kedua kelompok tersebut dapat disebut sebagai pengaruh dari intervensi atau perlakuan
(8). Penentuan variasi dosis, didasarkan pada uji pendahuluan yang telah dilakukan di Laboratorium Kimia Jurusan Kesehatan Lingkungan, Politeknik Kesehatan Banjarmasin meliputi perlakuan variasi dosis yaitu Abu sekam padi 58 gram; 59 gram; 60 gram; 61 gram; 62 gram dan Poly Aluminium Chloride 0,5 gr dalam $1000 \mathrm{ml}$ sampel limbah cair sasirangan.Kemudian perlakuan variasi dosis Abu sekam padi 58 gram; 59 gram; 60 gram; 61 gram; 62 gram dan Poly Aluminium Chloride 1 gr dalam $1000 \mathrm{ml}$ sampel limbah cair sasirangan. Pengujian dilakukan sebanyak 3 kali pengulangan dan setiap perlakuan memerlukan air limbah sasirangan sebanyak $36000 \mathrm{ml}$ atau 36 Liter.

Populasi dalam penelitian ini adalah seluruh limbah cair hasil produksi pembuatan kain sasirangan yang berada di Industri sasirangan "Oriens Handycraft" Landasan Ulin Kota Banjarbaru. Sampel penelitian ini adalah limbah cair sasirangan dari hasil produksi pembuatan kain sasirangan yang mewakili seluruh populasi. pengulangan Sampel yang digunakan dalam eksperimen ini berjumlah 36 sampel dengan 3 sampel sebelum yang berbeda pada 3 kali pengulangan. Pengambilan sampel ini di lakukan dengan metode Grab Sampling, dimana sampel diambil secara langsung diakhir proses pewarnaan kain sasirangan mewakili keadaan air limbah pada saat itu juga dari suatu tempat.

Variabel yang diteliti dalam penelitian ini adalah Abu sekam padi, Poly Aluminium Chloride, zat warna, $\mathrm{pH}$ dan suhu.

$\begin{array}{ccc}\text { Data diperoleh dari } & \text { hasil } \\ \text { pengamatan, } & \text { pengambilan } & \text { dan }\end{array}$ pemeriksaan sampel limbah cair industri sasirangan "Oriens Handycraft" serta buku-buku dan jurnal penelitian lain yang berhubungan dengan penelitian ini. Uji statistik yang digunakan yaitu One Way Annova untuk mengetahui apakah terdapat perbedaan rata-rata antara lebih dari dua group sampel. Satu arah adalah sumber keragaman yang dianalisis hanya berlangsung satu arah yaitu antar 
perlakuan (Between Group). Adapun faktor lain yang berpotensi mempengaruhi keragaman data dimasukkan kedalam Galat (within Group) dan sebisa mungkin dikontrol, sehingga jenis uji ini umumnya dilakukan pada rancangan perlakuan yang faktor-faktor lingkungannya dapat dikontrol. Alternatif lain jika hasil dari uji One Way Anova data distribusinya tidak normal adalah Uji Kruskal Wallis dan Uji U(Mann Whitney Test). Uji Kruskal Wallis adalah uji nonparametrik yang tujuannya untuk menentukan adakah perbedaan signifikan secara statistik antara dua atau lebih kelompok variabel independen pada variabel dependen yang berskala data numerik (interval/rasio) dan skala ordinal (9). Uji ini identik dengan Uji One Way Anova pada pengujian parametris. Selain sebagai uji alternatif, kegunaan lain adalah sebagai perluasan dari uji Mann Whitney U Test, Uji Mann Whitney U Test adalah uji non parametris yang digunakan untuk mengetahui perbedaan median 2 kelompok bebas apabila skala data variabel terikatnya adalah ordinal atau interval/ratio tetapi tidak berdistribusi normal. diketahui bahwa uji tersebut hanya dapat digunakan pada 2 kelompok variabel dependen (10).

\section{HASIL DAN PEMBAHASAN}

Kadar Warna Limbah Cair Sebelum dan Sesudah PengolahanPenelitian yang dilakukan adalah berupa uji coba menggunakan Abu sekam padi dan Poly Aluminium Chloride untuk menurunkan kadar warna. Kegiatan uji cobanya dilakukan pada hari senin tanggal 25 April 2016 di Laboratorium Kimia Jurusan Kesehatan Lingkungan Poltekkes Kemenkes Banjarmasin dan pemeriksaan warna dilakukan pada Balai Riset dan Standarisasi Industri (Baristand) Banjarbaru. Berikut adalah grafik penurunan kadar warna sebelum dan sesudah perlakuan berdasarkan dosis Abu sekam padi dan Poly Aluminium Chloride.

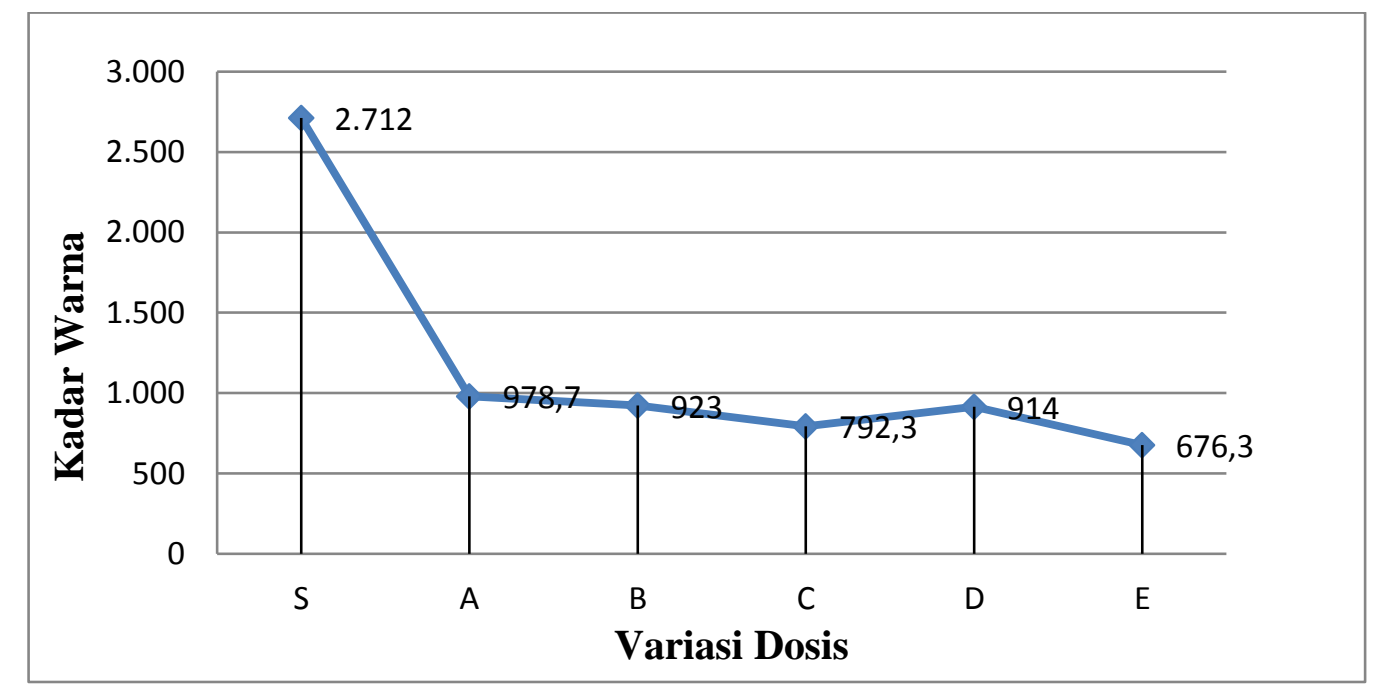

Gambar 1 Grafik Variasi Dosis Abu Sekam Padi dan PACl 0,5 gr Terhadap Kadar Warna

Keterangan :

$\begin{array}{ll}\text { PACl } & =\text { Poly Aluminium Chloride } \\ \text { S } & =\text { Sebelum } \\ \text { A } & =\text { Dosis Abu sekam padi } 58 \mathrm{gr} \text { dan Poly Aluminium Chloride } 0,5 \mathrm{gr} \\ \mathrm{B} & =\text { Dosis Abu sekam padi } 59 \mathrm{gr} \text { dan Poly Aluminium Chloride } 0,5 \mathrm{gr} \\ \mathrm{C} & =\text { Dosis Abu sekam padi } 60 \mathrm{gr} \text { dan Poly Aluminium Chloride } 0,5 \mathrm{gr} \\ \mathrm{D} & =\text { Dosis Abu sekam padi } 61 \mathrm{gr} \text { dan Poly Aluminium Chloride } 0,5 \mathrm{gr} \\ \mathrm{E} & =\text { Dosis Abu sekam padi } 62 \mathrm{gr} \text { dan Poly Aluminium Chloride } 0,5 \mathrm{gr}\end{array}$

Berdasarkan Gambar 1 grafik penurunan kadar warna terdapat pada dosis optimum Abu sekam padi 60 gr dan Poly Aluminium Chloride 0,5 gr. 


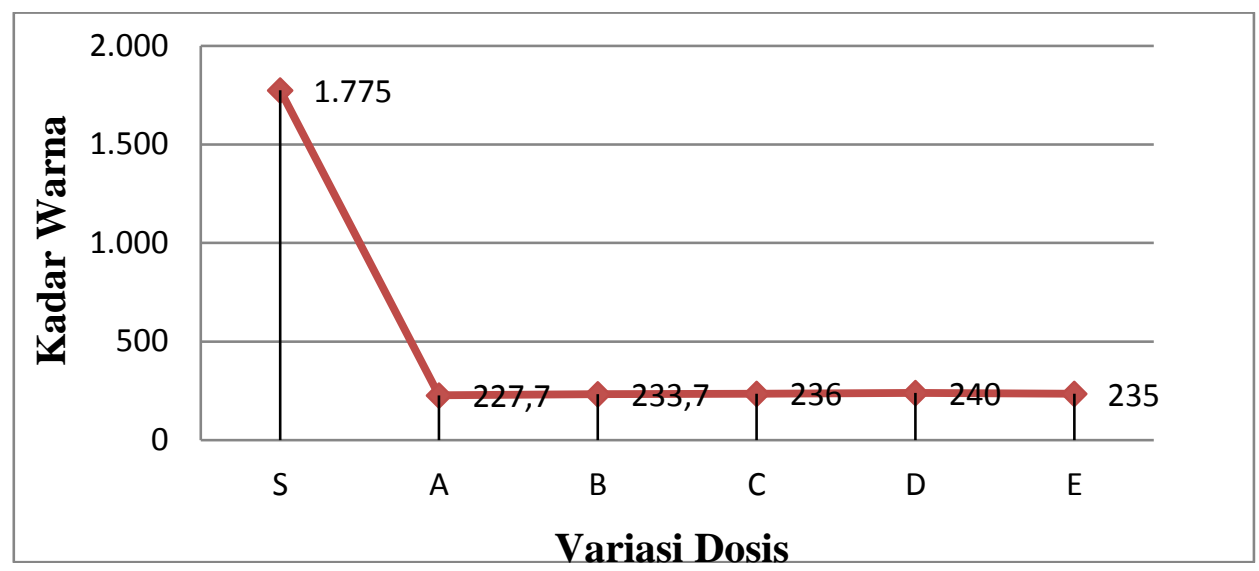

Gambar 2 Grafik Variasi Dosis Abu Sekam Padi dan PACl 1 gr Terhadap Kadar Warna

Keterangan :

$\begin{array}{ll}\mathrm{PACl} & =\text { Poly Aluminium Chloride } \\ \mathrm{S} & =\text { Sebelum } \\ \mathrm{A} & =\text { Dosis Abu sekam padi } 58 \mathrm{gr} \text { dan Poly Aluminium Chloride } 1 \mathrm{gr} \\ \mathrm{B} & =\text { Dosis Abu sekam padi } 59 \mathrm{gr} \text { dan Poly Aluminium Chloride } 1 \mathrm{gr} \\ \mathrm{C} & =\text { Dosis Abu sekam padi } 60 \mathrm{gr} \text { dan Poly Aluminium Chloride } 1 \mathrm{gr} \\ \mathrm{D} & =\text { Dosis Abu sekam padi } 61 \mathrm{gr} \text { dan Poly Aluminium Chloride } 1 \mathrm{gr} \\ \mathrm{E} & =\text { Dosis Abu sekam padi } 62 \mathrm{gr} \text { dan Poly Aluminium Chloride } 1 \mathrm{gr}\end{array}$

Berdasarkan Gambar 2 grafik penurunan kadar warna terdapat pada dosis optimum Abu sekam padi 58 gr dan Poly Aluminium Chloride $1 \mathrm{gr}$.
Berikut adalah grafik efisiensi penurunan kadar warna berdasarkan dosis Abu sekam padi dan Poly Aluminium Chloride.

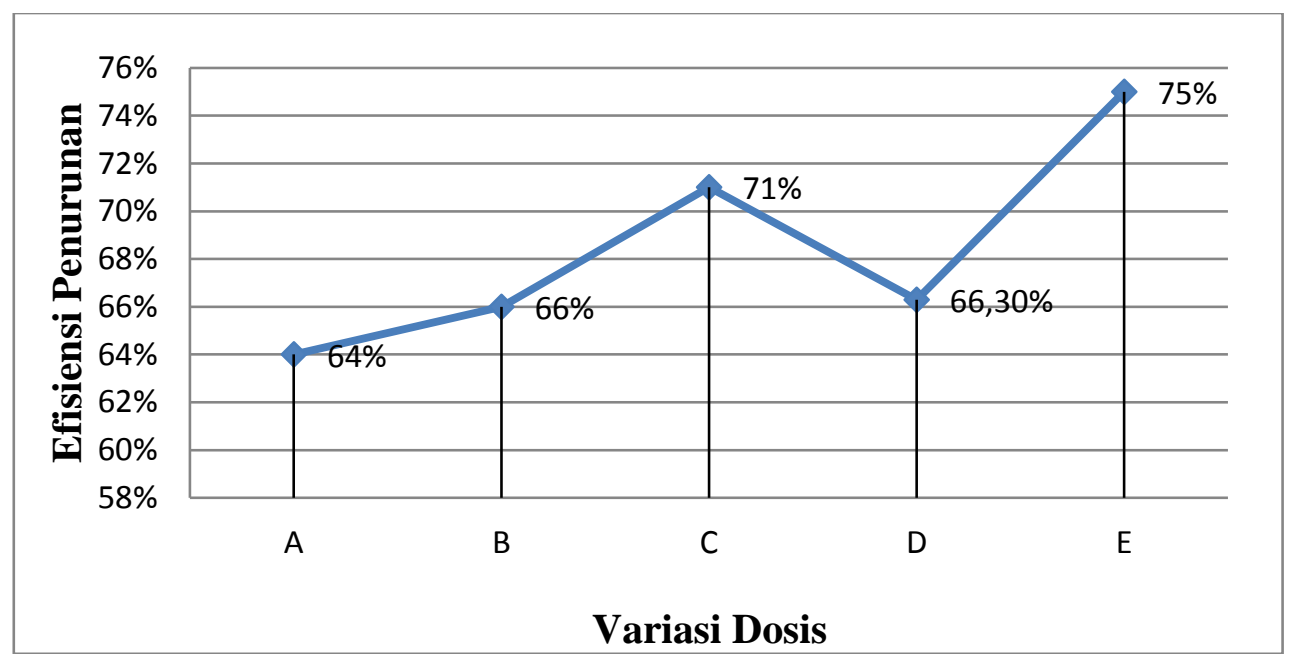

Gambar 3 Grafik Efisiensi Penurunan Kadar Warna Dosis Abu Sekam Padi dan PACl 0,5 gr

Keterangan :
$\mathrm{PACl}=$ Poly Aluminium Chloride
$\mathrm{A}=$ Dosis Abu sekam padi $58 \mathrm{gr}$ dan Poly Aluminium Chloride 0,5 gr
$\mathrm{B}=$ Dosis Abu sekam padi $59 \mathrm{gr}$ dan Poly Aluminium Chloride 0,5 gr
$\mathrm{C}=$ Dosis Abu sekam padi $60 \mathrm{gr}$ dan Poly Aluminium Chloride $0,5 \mathrm{gr}$
$\mathrm{D}=$ = Dosis Abu sekam padi $61 \mathrm{gr}$ dan Poly Aluminium Chloride 0,5 gr 
Berdasarkan Gambar 3 grafik hasil efisiensi penurunan kadar warna limbah cair sasirangan berkisar antara 64\% $75 \%$.

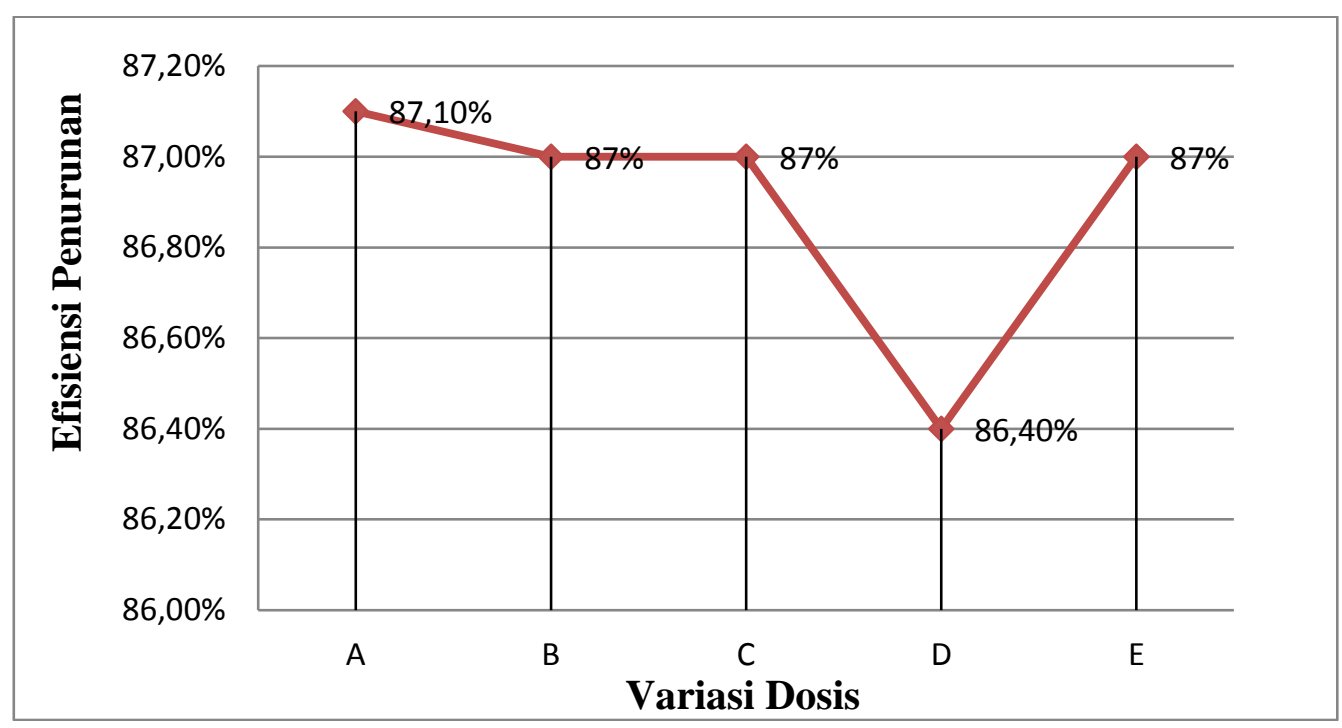

Gambar 4 Grafik Efisiensi Penurunan Kadar Warna

Dosis Abu Sekam Padi dan PACl 1 gr

Keterangan :

$\mathrm{PACl}=$ Poly Aluminium Chloride

A = Dosis Abu sekam padi $58 \mathrm{gr}$ dan Poly Aluminium Chloride $1 \mathrm{gr}$

B = Dosis Abu sekam padi $59 \mathrm{gr}$ dan Poly Aluminium Chloride $1 \mathrm{gr}$

C = Dosis Abu sekam padi $60 \mathrm{gr}$ dan Poly Aluminium Chloride $1 \mathrm{gr}$

D = Dosis Abu sekam padi $61 \mathrm{gr}$ dan Poly Aluminium Chloride $1 \mathrm{gr}$

$\mathrm{E} \quad=$ Dosis Abu sekam padi $62 \mathrm{gr}$ dan Poly Aluminium Chloride $1 \mathrm{gr}$

Berdasarkan Gambar 4 grafik hasil efisiensi penurunan kadar warna limbah cair sasirangan berkisar antara 86,4\% $87,1 \%$.

Uji normalitas dengan KolmogorovSmirnov dan Shapiro-Wilk data tidak berdistribusi normal sehingga data tidak dapat dilanjutkan ke One Way Anova. Berdasarkan Uji Kruskal Wallis dapat disimpulkan bahwa ada perbedaan antara rata-rata pemberian dosis pada kelompok kontrol dan kelompok perlakuan dan kesimpulan dari hasil uji Mann-Whitney berarti bahwa pemberian dosis Abu sekam padi dan Poly Aluminium Chloride 1 gr lebih efektif daripada pemberian dosis Abu sekam padi dan Poly Aluminium Chloride 0,5 gr.

\section{PEMBAHASAN}

Limbah cair sasirangan termasuk dalam kategori limbah tekstil, yang mana parameter kadar warna menjadi ciri khas dari limbah tekstil tersebut. Limbah cair sasirangan memiliki kadar warna awal (sebelum) sebesar 280 PtCo, secara fisik terlihat berwarna sangat pekat dan berbau tajam yang disebabkan dari campuran bahan pewarna kimia yang digunakan. Apabila limbah tersebut dibuang langsung ke lingkungan secara terus menerus akan memiliki dampak terhadap ketidak seimbangan ekosistem. Limbah cair sasirangan diperoleh dari bak pewarnaan sebelum limbah cair tersebut dibuang ke parit atau selokan. Untuk melihat kemampuan Abu sekam padi dan Poly Aluminium Chloride perlakuan pengadukan pada Sebelum dan perlakuan penambahan Abu sekam padi dan Poly Aluminium Chloride dilakukan dengan alat Jartest. Jartest terdiri dari rangkaian stirrer (pengaduk) yang berputar dalam wadah berupa beaker glass dengan rentang kecepatan putaran dan waktu. Kecepatan putaran terdiri dua bagian, 
putaran lambat dan putaran cepat. Jartest digunakan untuk memperkirakan dosis maksimal yang akan digunakan dalam proses pengolahan limbah.

Dilakukan pengadukan selama 60 menit, yang terdiri dari pengadukan cepat sebesar 150 rpm selama 5 menit untuk menghomogenkan air dengan koagulan dan dilanjutkan dengan pengadukan lambat sebesar $30 \mathrm{rpm}$ selama 60 menit untuk mengendapkan flok yang dihasilkan. Kemudian, Proses pengendapan (sedimentasi) dengan cara didiamkan selama 60 menit setelah terbentuk endapan dilakukan penyaringan dengan kertas saring yang berguna untuk mencegah hasil menjadi bias saat dilakukan pengukuran akibat endapan yang terbentuk ${ }^{(11)}$.

Berdasarkan hasil uji pendahuluan, dosis optimum untuk pengolahan limbah cair sasirangan dengan menggunakan abu sekam padi dan Poly Aluminium Chloride adalah $60 \mathrm{gr}+0,5 \mathrm{gr}$ PACl. Maka, dengan memberikan perlakuan untuk mengetahui pengaruh penambahan variasi dosis abu sekam padi sebanyak 58 gram; 59 gram; 60 gram; 61 gram dan 62 gram dengan variasi dosis Poly Aluminium Chloride yaitu 0,5 gram dan 1 gram terhadap penurunan kadar warna limbah cair sasirangan.

Pada penelitian ini perlakuan sampel sebelum di uji atau di tambahkan dosis abu sekam padi dan Poly AluminiumChloride adalah menghomogenkan sampel terlebih dahulu, kemudian mengambil sampel yang homogen tadi sesuai dengan kebutuhan dari penelitian. Penelitian ini menggunakan 6 buah beaker glass yang masing-masingnya diisi dengan air limbah sasirangan sebanyak $1000 \mathrm{ml}$.

Berdasarkan hasil penelitian didapatkan nilai sampel air limbah sasirangan sebelum perlakuan sebesar 2.712 PtCo pada variasi dosis abu sekam padi 58 gram; 59 gram; 60 gram; 61 gram dan 62 gram dan 0,5 gr Poly Aluminium Chloride, kemudian pada variasi dosis abu sekam padi 58 gram; 59 gram; 60 gram; 61 gram dan 62 gram dan 1 gr Poly Aluminium Chloride didapatkan nilai sampel air limbah sasirangan sebelum perlakuan sebesar 1.775 PtCo, dibandingkan dengan peraturan Gubernur Daerah Istimewa Yogyakarta Nomor 07 Tahun 2010 angka baku mutu untuk parameter warna adalah 50 PtCo maka hasil sampel limbah sasirangan sebelum perlakuan melebihi baku mutu yang telah ditetapkan. Kemampuan Abu sekam padi dan Poly Aluminium Chloride dalam menyerap kadar warna menjadi kurang maksimal karena abu sekam padi aktif dan Poly Aluminium Chloride hanya dapat bekerja pada $\mathrm{pH}$ 6,5 - 7 sehingga sampel limbah cair sasirangan yang $\mathrm{pH}$ nya adalah 8 harus di kondisikan terlebih dahulu.Pada hasil variasi dosis Abu sekam padi dengan penambahan dosis Poly Aluminium Chloride 0,5 gr didapatkan kadar warna berkisar 676,3 PtCo hingga 978,7 PtCo, hasil tersebut melebihi angka baku mutu parameter warna yaitu 50 PtCo menurut peraturan Gubernur Daerah Istimewa Yogyakarta Nomor 07 Tahun 2010 dan untuk variasi dosis Abu sekam padi dengan penambahan dosis Poly Aluminium Chloride 1 gr didapatkan kadar warna berkisar 227,7 PtCo hingga 240 PtCo, sehingga hasil tersebut melebihi angka baku mutu parameter warna yaitu 50 PtCo menurut peraturan Gubernur Daerah Istimewa Yogyakarta Nomor 07 Tahun 2010(12).

Fungsi dari Abu sekam padi yang di aktivasi dengan menggunakan $\mathrm{H}_{3} \mathrm{PO}_{4}$ (Asam Phospat) pada penelitian adalah untuk memperluas rongga atau pori karbon aktif karena molekul - molekul pengaktif akan teradsorbsi oleh bahan karbon yang akan melarutkan pengotorpengotor yang berada dalam pori karbon seperti mineral - mineral anorganik atau zat warna limbah cair sasirangan. Kemudian fungsi Poly Aluminium Chloride pada penelitian ini adalah untuk mempercepat reaksi dari Abu sekam padi aktif dan mendestabilisasi partikel sehingga terbentuk mikroflok kemudian digumpalkan menjadi makroflok yang dapat diendapkan melalui proses flokulasi. Proses penggumpalan ini tergantung pada waktu dan pengadukan lambat dalam air. 
Beberapa faktor yang mempengaruhi hasil nilai dari kadar warna yang berbeda-beda pada variasi dosis Abu sekam padi dan Poly Aluminium Chloride adalah pada saat perlakuan sampel sebelum di tambahkan Variasi dosis Abu sekam padi dan Poly Aluminium Chloride sampel tidak homogen, sampel warna limbah cair sasirangan sebelum perlakuan tidak disaring terlebih dahulu untuk mengurangi endapan yang terlarut.

Pada Gambar 1 grafik variasi dosis Abu sekam padi dan Poly Aluminium Chloride 0,5 gr terhadap kadar warna dengan dosis optimum terdapat pada dosis Abu sekam padi 60 gr dan Poly Aluminium Chloride 0,5 gr penurunan kadar warna sebesar 792,3 PtCo , dikarenakan dosis abu sekam padi yang ditambahkan selalu meningkat diiringi dengan penurunan kadar warna, namun pada variasi dosis abu sekam padi 61 gram dan Poly Aluminium Chloride 0,5 gr kadar warna mengalami kenaikan hingga 914 PtCo sehingga dapat dikatakan bahwa Abu sekam padi $60 \mathrm{gr}$ dan Poly Aluminium Chloride 0,5 gr merupakan titik terendah penurunan kadar warna dan faktor lain seperti perlakuan sampel sebelum ditambahkan dosis tidak homogen serta terdapat endapan terlarut karena tidak disaring sebelum perlakuan. Sedangkan Pengaruh variasi dosis pada Gambar 2 grafik variasi dosis Abu sekam padi dan Poly Aluminium Chloride 1 gr terhadap kadar warna dengan dosis optimum terdapat pada dosis Abu sekam padi $58 \mathrm{gr}$ dan Poly Aluminium Chloride 1 gr ini terjadi dikarenakan dosis abu sekam padi yang ditambahkan rendah diiringi dengan penurunan kadar warna namun dimulai pada variasi dosis abu sekam padi 59 gram kadar warna menjadi meningkat, dan faktor lain seperti perlakuan sampel sebelum ditambahkan dosis tidak homogen serta terdapat endapan terlarut karena tidak disaring sebelum perlakuan

Pada Gambar 3 grafik efisiensi penurunan kadar warna dosis Abu Sekam Padi dan Poly Aluminium Chloride 0,5 gr yang tinggi terdapat pada variasi dosis Abu sekam padi 62 gr dan Poly Aluminium Chloride 0,5 gr yaitu sebesar $75 \%$ dan Pada Gambar 4 grafik efisiensi penurunan kadar warna dosis Abu Sekam Padi dan Poly Aluminium Chloride 1 gr yang tinggi terdapat pada variasi dosis Abu sekam padi 58 gr dan Poly Aluminium Chloride 1 gr yaitu sebesar $87,1 \%$.

Berdasarkan hasil dari pemeriksaan kadar warna limbah cair sasirangan Dosis optimum pada penelitian ini terdapat pada variasi dosis Abu sekam padi $58 \mathrm{gr}$ dan Poly Aluminium Chloride 1 gr dengan nilai kadar penurunannya adalah 227,7 PtCo serta efisiensi penurunan 87,10\% walaupun penurunan kadar warna nya bersifat stationer namun jika dibandingkan dengan variasi dosis $\mathrm{Abu}$ sekam padi 60 gr dan Poly Aluminium Chloride 0,5 gr penurunan kadar warnanya mencapai 792,3 PtCo lebih tinggi daripada penurunan kadar warna dosis Abu sekam padi 58 gr dan Poly Aluminium Chloride $1 \mathrm{gr}$ dan efisiensi penurunannya adalah $71 \%$ masih rendah.

\section{KESIMPULAN DAN SARAN}

Kadar warna sebelum perlakuan adalah 2712 PtCo, dengan variasi dosis Abu sekam padi 58 gr; 59 gr; 60 gr; 61 gr dan 62 gr serta penambahan dosis Poly Aluminium Chloride0,5 gr sesudah perlakuan kadar warna berkisar 676,3 PtCo hingga 978,7 PtCo. Kadar warna sebelum perlakuan adalah 1775 PtCo pada variasi dosis Abu sekam padi 58 gr; 59 gr; 60 gr; 61 gr dan 62 gr serta penambahan dosis Poly Aluminium Chloride 1 gr didapatkan kadar warna berkisar 227,7 PtCo hingga 240 PtCo.Dosis optimum pada penelitian ini terdapat pada variasi dosis Abu sekam padi 58 gr dan Poly Aluminium Chloride 1 gr dengan nilai kadar penurunannya adalah 227,7 PtCo serta efisiensi penurunan 87,10\%.Hasil Uji Statistik Kruskal Wallis menunjukkan bahwa ada perbedaan antara rata-rata pemberian dosis pada kelompok kontrol (sebelum) dan kelompok perlakuan. Berdasarkan uji Mann-Whitney (U Test) pemberian dosis Abu sekam padi dan PACl 1 gr lebih efektif daripada pemberian dosis $\mathrm{Abu}$ sekam padi dan PACl 0,5 gr.

Dapat disarankan bagi pemerintah agar memberikan kebijakan yang sesuai 
tentang baku mutu limbah cair serta memperhatikan pembuangan limbah industri sasirangan dan mengadakan penyuluhan bagi pelaku usaha tentang pengelolaan limbah tekstil. Untuk peneliti selanjutnya dapat melanjutkan penelitian untuk menganalisa nilai $\mathrm{pH}$, Pengaktifan abu sekam padi, waktu kontak dan kandungan logam berat.

\section{KEPUSTAKAAN}

1. Pratiwi, Y. (2010). Penentuan Tingkat Pencemaran Limbah Industri Tekstil berdasarkan Nutrition Value Coeficient Bioindikator. Jurnal Teknik.

2. Akbar, I. A. (2015, Febuary 11). Potensi dan Dampak Limbah Sasirangan. Dipetik january 27, 2016, dari Ipan AA: http://ipanaa021.wordpress.co.id/20 15/02/potensi-dan-dampak-limbahsasirangan.html

3. Rasmidi. (2013, July 31). Pemanfaatan sekam padi. Dipetik January 27, 2016,dari Waras Farm: https://warasfarm.wordpress.com/2 013/07/31/pemanfaatan-sekampadi-dalam-sebagai-media-tanamdan-pupuk/

4. Harsono, H. (2003). Pembuatan Silika Amorf dari Silika Sekam Padi . Jurnal Ilmu Dasar, 98-103.

5. Cahyonugroho, O. H. (2007). Kinetika Adsorpsi Warna Limbah Tekstil dengan Abu Sekam Padi Menggunakan Reagen Tawas. Jurnal Teknik Kimia Volume 1 no. 2, 59-64.

6. Isna. (2014, April). Kamus $Q$ Pengertian dan Definisi. Dipetik January 27, 2016, dari Adsorben adalah:

http://www.kamusq.com/2013/04/ adsorben-adalah-pengertian-dandefinisi.html

7. Peraturan Gubernur Daerah Istimewa Yogyakarta Nomor 07 Tahun 2010, Tentang Baku Mutu Limbah Cair Industri Batik

8. Notoatmodjo, D. S. (2002). Metodologi Penelitian Kesehatan. Jakarta: PT. Asdi Mahasatya.

9. Hidayat, A. (2014, July 17). Kruskall Wallis H. Dipetik July 21, 2016, dari
Statiskian.com:

http://www.statistikian.com/2014/0

7/kruskall-wallis-h.html

10. Hidayat. (2014, April 08). Mann Whitney Test. Dipetik July 21, 2016, dari Statistikian: http://www.statistikian.com/2014/0 4/mann-whitney-u-test.html

11. Ani, M. I. (2000). Techno-Economics Of Rice Husk Pyrolysis Convertion With Catalytic Threatment To Produce liquid Fuel. Bioresource Technology, 67-75.

12. Peraturan Gubernur Provinsi Kalimantan Selatan Nomor 36 Tahun 2008, Tentang Baku Mutu Limbah Cair Bagi Kegiatan Industri, Hotel, Restoran, Rumah Sakit, Domestik dan Pertambangan. 